\title{
Capturing humanitarian war: the collusion of violence and care in US-managed military detention
}

\author{
Richard Nisa \\ Department of Social Sciences and History, Fairleigh Dickinson University, 285 Madison \\ Avenue, Madison, NJ 07940, USA; e-mail: nisa@fdu.edu \\ Received 24 February 2014; in revised form 10 October 2014; \\ published online 27 February 2014
}

\begin{abstract}
In this paper I explore the complex economies of violence that circulate through the US military's enactments of battlefield capture and military detainment. I highlight the ways in which these practices relate to the humanitarian objective of carrying out warfare both for and with humanity. I first outline the emergence of an explicitly protective custody within the landscape of war, describing the broad historical contours of war prisoner treatment. I then detail the ways in which humanitarian law's call to care for detained enemy bodies has itself become linked with highly specific forms of political and bodily violence. Next, I argue that this copractice of care and violence in the camps is underpinned by a relational understanding of humanitarianism. Finally, I turn my attention to the ways in which the battlefield encounter has become an increasingly technical enterprise, one in which questions surrounding the ethical treatment of prisoners are subsumed into an evolving assemblage of spaces, means of data collection, and discursive performances that reframe the limits of military violence and generate new vulnerabilities.
\end{abstract}

Keywords: military detention, humanitarianism, care and violence, prisoners of war, biometrics

\section{Introduction: controlling the contact zone}

Towards the later part of 1965, if a person were to rummage through the pockets of a US or South Vietnamese soldier on their first mission in Southeast Asia, they would likely have come upon a $3 " \times 5^{\prime \prime}$ card that had been printed for him by the Military Assistance Command, Vietnam. Issued to all deployed personnel, the card - titled The Enemy in Your Hands - was meant to remind soldiers of their basic training, when they watched instructional videos and took short classes detailing their responsibilities under the III Geneva Convention of 1949 Relative to the Treatment of Prisoners of War (GPW). It offered a simple set of guidelines for the soldier to follow in the eventuality that he encountered and detained a person on the battlefield.

\section{THE ENEMY IN YOUR HANDS}

As a member of the US Military Forces, you will comply with the Geneva Prisoner of War Convention of 1949 to which your country adheres. Under this Convention:

\section{YOU CAN AND WILL}

Disarm your prisoner

Immediately search him thoroughly

Require him to be silent

Segregate him from other prisoners

Guard him carefully

Take him to the place designated by your commander

YOU CANNOT AND MUST NOT

Mistreat your prisoner

Humiliate or degrade him 
Take any of his personal effects which do not have significant military value Refuse him medical treatment if required and available. ${ }^{(1)}$

The chaos of the battlefield and the long difficult operations far from military outposts meant that these cards did not stay in soldiers' uniforms for long, but the reasons behind their issuance were clear. Personnel in the field, away from the oversight and governing eyes of the US command structure, were capable of seeking unsanctioned personal retribution on civilians or combatants that would exceed the limits articulated by the GPW, thereby compromising the military effort and potentially making the state liable to war crimes litigation. The state, in its attempts to retain its monopoly on legitimate uses of violence, needed to train soldiers how to perform at this limit between lethal battlefield violence on the one hand, and legal care and custody on the other. The performance of wartime detainment thus had to be regulated, observed, and prepared for: the rage and brutality of war needed to be channeled in ways that were consistent with humanitarian objectives while remaining militarily useful (Khalili, 2012). In the same way that a soldier learns to fire a gun or clear and hold terrain, here they had to learn to use restraint and emotional control. While remaining prepared to kill, they needed to be ready to capture.

The dynamics of detainment begin in these frequently improvisational, disorderly, or even invisible 'contact zones', in the spaces of interpellation between agents of military force and the subject position of 'enemy', in the iterative and multiple ways in which power seeks to give shape to captive populations, and populations aim to counter and contest this performance of security. Mary Louise Pratt defines these contact zones as "social spaces where disparate cultures meet, clash, and grapple with each other, often in highly asymmetrical relations of domination and subordination" (1992, page 4). But they are not just contact zones between widely divergent cultures - areas of transculturation between Western visuality and the occupied Other. They are also points of contact between military violence and ostensibly humanitarian aims; between technologies of annihilation and technologies aimed at population management and life affirmation; and between the disorder and intimacy of encounters in a warzone and particular classification schemes, probability calculations, and technical apparatuses aimed at cutting through the fog of war.

Questions regarding how to govern action in these diverse and emotionally charged spaces have long confounded military planners and human rights advocates. The former are concerned that excessive violence is militarily counterproductive; the latter target disproportionate violence as ethically problematic. In performing capture, evacuation, and detainment the space of the battle and the space of detention speak to and through each other, a simultaneous performance of battlefield violence and a logic of humanitarian care. The military needs to prepare, discipline, and mold soldiers' behavior in light of the eventuality that they encounter, detain, and move other bodies. "Between combat and surrender", writes Gabriel Palmer-Fernández, "between the right to kill enemy soldiers and the duty to protect them, lies a zone of ambiguity wherein it is not clear whether that right or that duty is paramount" (2001, page 144).

In this paper I interrogate the ways in which these "zones of ambiguity" trace across many of the legal and spatial practices of wartime detention. I highlight the fact that the prison camp is not a singular space of exception (Agamben, 2005), but "an emerging and continually changing assemblage of spatial tactics" (Martin and Mitchelson, 2009, page 467). ${ }^{(2)}$

(1) “Tab A to Appendix II to Annex L: Detainee treatment Card”, 29 December 1971, RG 389/290/76/6/ Shelf 3, Box 39. Record of the Provost Marshal General 1941-: POW/ Civilian Internee Information Center; National Archives at College Park, MD.

${ }^{(2)}$ There is a growing body of excellent work on carceral geography beyond the scope of this paper that more specifically addresses the dynamics of detention and imprisonment (see, among others, Bonds, 2006; Gilmore, 2007; Loyd et al, 2012; Moran, 2013). 
My primary focus is US-managed military detainment practices after the signing of the GPW. However, the relationship between wartime detainee handling and regimes of care predates the GPW in substantive ways. Therefore in the first section I situate the enemy prisoner in a longer historical context, one that details the complex relationship between the sequestered body and the use of lethal force.

I then describe the emergence of an explicitly protective custody for wartime captives, detailing the ways in which humanitarian law's mid-20th-century call to care for detained enemy bodies has become linked with highly specific forms of political and bodily violence. While humanitarianism was "born" (Fassin, 2010, page 240) on the battlefield as a response to war's brutality, I here focus on the practices of wartime detention to outline the ways that humanitarian aims have been integrated into the violence of war itself.

Next, I argue that this copractice of care and violence in the camps is underpinned by a relational understanding of humanitarianism. I underscore the ways in which practices of so-called humanitarian violence (Weizman, 2012) revolve around strategic representations of the enemy, rather than any kind of clear benevolence or compassionate ethic that works in the name of a universal humanity (Edkins, 2003).

In the paper's final section I turn my attention to the ways in which the Vietnam-era encounter sketched out by The Enemy in Your Hands is today an increasingly technical enterprise, one in which the difficult questions of right and wrong that frame battlefield decision making are subsumed into an evolving assemblage of spaces, technologies of data collection and organization, and discursive performances that reframe the limits of military violence and generate new vulnerabilities. I contend that the introduction of networked technologies such as handheld digital biometrics into these contact zones means soldiers are increasingly tasked with evermore-specific physical and procedural objectives that the military hopes will generate accurate, ethical, and automated decisions. This focus on technical devices displaces the soldier's personal role in the "practical evaluation of lives" (Fassin, 2010, page 244), and recasts the forms of care at work in the battlefield encounter through a highly depoliticized lens of digital networks and algorithmic decision making.

\section{Governing wartime detention: the collusion of violence and care}

The captured body has long been part of the calculus of war. From the earliest days of organized warfare those apprehended on the battlefield were either killed or retained as slaves and forced to work for their captors. At different times and as forms of warfare shifted, enemy prisoners of war (EPW) were frequently used as collateral to secure ransom or in exchange for captured officers. ${ }^{(3)}$ Massacres of EPWs have been frequent across the history of organized violence. If captives survived and were allowed to return home at war's end they were often killed for being captured and failing to fight to their own deaths. The captives' expendability did not mean that they were considered unimportant, or beyond the scope of military strategy. Early 19th-century military theorist Carl von Clausewitz labeled prisoners and captured weapons as the "objects by which victory is mainly personified", such that the military engagement "will most likely be planned so as to obtain them." In this, he saw "the destruction of the enemy by killing and wounding ... only as a means" to achieving war's desired ends (von Clausewitz, 1989, page 233).

Capturing prisoners thus has tactical and intelligence value, has at times led to the production of a vital labor force for the captor, and has been a central aspect of propaganda and counterintelligence (Davis, 1977). Yet with few exceptions-like the recent kill/capture operations - war has rarely been conducted with capture in mind. Rather, war is consistently understood in reference to lethality, and detainees are seen as a complicated by-product

(3) For an international historical perspective on EPWs, see Krammer (2007) and Scheipers (2010). For American handling of EPWs, see Doyle (2010), Gebhardt (2005), and Springer (2010). 
(Scheipers, 2010) or a distraction from war's strategic objectives. Consider Rupert Smith's recent work, in which he argues that war as set battle pieces, strategic fronts, and uniformed troops (he terms this industrial war) no longer exists - he also makes the claim that the sole utility of military force is to "kill people and destroy things" (Smith, 2007, page 8). And yet, in spite of this destructive focus, the performance of both industrial war and what he views as its replacement, so-called 'wars amongst the people', have utilized detainment, not as an effect of force, but as a specific manifestation thereof. The capture, distribution, treatment, and physical labor of detainee populations come to shape the strategic and tactical contours of battlefield violence. Detainment lends military force an element of utility that is not life threatening and destructive, but life sustaining.

So central was the use (and abuse) of captives to the functioning of war's violence that in the middle of the 19th century a series of national and international legal provisions were deemed necessary to assure that the captive "be held in protective custody, the only purpose being to prevent him from further participating in the war" (Prugh, 1955, page 124, italics mine). In 1863 President Lincoln signed the Lieber Code, a set of rules governing the treatment of wartime detainees by Union troops in the US Civil War. This "seminal event" (Neff, 2010, page 58) in the legal protection of EPWs stipulated, among other things, that:

"A prisoner of war is subject to no punishment for being a public enemy, nor is any revenge wreaked upon him by the intentional infliction of any suffering, or disgrace, by cruel imprisonment, want of food, by mutilation, death, or any other barbarity" (Lieber, 1863, section 56).

As Simon Ried-Henry notes, one of the key outcomes of the Lieber Code's imbrication of the "vocabulary of humanitarianism" with the "civilising legal discourse of the liberal state itself" was "to replace a purely practical theory of warfare with a specifically moral theory of warfare" (2013, page 423). Changes in the legal framework of military detainment would expand into an international context through the 19th and into the 20th century.

The Hague Conventions of 1899 and 1907, the Geneva Convention of 1929, and the III Geneva Convention of 1949 (GPW) each engaged with evermore particular questions of who and how persons could be detained in wartime and addressed the conditions under which the enemy body could be forced to labor. Each of these treaties sees wartime detainment not as a disciplinary tactic, nor a tool in the production of docile bodies (Foucault, 1979), but as a space to protect war fighters from the excesses of violent retribution-to place them hors de combat. These regulations emerge alongside an attempt to render war as an occurrence between legitimate states and to banish forms of violence that exceed or contradict this territorial imaginary as illegitimate or criminal.

In an effort to limit the use of unsanctioned individual deadly violence, for instance, the Hague Conventions famously place the responsibility for the well-being of the prisoner on the capturing government, "not in that of the individuals or corps who captured them" [International Conferences (The Hague), 1907, section 1, chapter 2, Article 4]. This displaced culpability from the individual to the state helps to explain why many state militaries have focused time and resources on developing new forms of training and management that target soldiers' bodily and emotional self-control.

It is important to note that these provisions are modeled on the type of symmetrical, idealized form of state-on-state warfare that was briefly dominant in the early 20th century. But this idealization of the geopolitical structure of war has rarely occurred. Even before the GPW were ratified by the US, the country was already embroiled in a war on the Korean peninsula where no party to the conflict had directly ratified the treaty: the UN Commandnot a state but a coalition of sixteen states fighting under US leadership — was a declared belligerent; the US had signed but not yet ratified the treaty (this would happen in 1955); neither recognized the Democratic People's Republic of Korea as a sovereign state; and 
the southern end of the peninsula was undergoing decolonization and lacked full sovereign statehood (Kim, 2011, page 169). Perhaps because of this mismatch between the apparent legitimacy offered through international humanitarian law (IHL) and the transformations of war technologies and practices, by 1975 legal scholars were already lamenting that " $t]$ hose present at Geneva ... hoped that prisoner treatment could be improved. A quarter century later, the bright optimism of Geneva has faded" (Zillman, 1975, page 237).

Nonetheless, these logics of care have entered into the spaces of state violence to such a degree that states, and state militaries, have successfully "co-opted humanitarianism for their interests" (Barnett, 2011, page 172) by utilizing humanitarian discourse "as both an enabler and a limit on state powers" (Reid-Henry, 2013, page 423) as they see fit. This tension is one particular manifestation of what Eyal Weizman calls the humanitarian present, an era that sees the collusion of "technologies of humanitarianism, human rights and humanitarian law with military and political power." It is in these spaces and through these mechanisms that "all political oppositions are replaced by the elasticity of degrees, negotiations, proportions and balances" (Weizman, 2012, page 4). Thus war in the humanitarian present is not simply "war for humanity; it is war carried out with humanity" (Zehfuss, 2012, page 864). Yet there remains a dissonance between the militarized distribution of 'humanity' and the use of lethal force, whether or not it occurs within a framework of proportionality and care.

Describing the paralyzing ambiguity that must exist on the ground below an American war plane tracing across the skies of Afghanistan, Slavoj Žižek calls this particular blending of humanitarianism and warfare the "ultimate image" of bare life: "one can never be sure whether it will be dropping bombs or food parcels" (Žižek, 2002, page 4; see also Anderson, 2011). Referring to what he called "humanitarian war", Rony Brauman (2004, page 398) likewise sees these practices as "the West's phantasm par excellence", in that it "considers itself to be the new Providence, from the sky dispensing life out of one hand and death out of the other."

The captured body, then, is in many ways a reflection of the paradoxical underpinnings of late modern war - that deadly violence is often used in the name of the preservation of the life of humanity itself (as imagined by specific populations in light of a state-centric view of war) (Dillon and Reid, 2009). A type of war-for-peace, late modern war is framed around an ontological condition that depends on the simultaneous performance of war and peace. ${ }^{(4)}$ This fluid and often paradoxical topology of violence is conveyed in Rupert Smith's claim that "[y] ou are acting on behalf of your enemy; you are even co-operating with him" (Pfanner, 2006, page 727).

Within the military detention compound, this form of humanitarian violence is perhaps best illustrated by force-feeding chairs used at the Guantánamo Bay Strategic Internment Facility. A far cry from the representations of disorder often conveyed by images of war prisons, the clinical chair (and the exam rooms in which they often sit) presents a vision of Guantánamo as a medically sterile and environmentally controlled institution. Yet it also highlights a form of control in which 'care and custody' of the human body, performed by way of a series of medical processes and procedures (including forced immobilization and the placement of a nasogastric tube to administer nutrition) is nonetheless, for the detainee, still physically debilitating and mentally abusive.

US military detention policy and IHL dictate that prisoners should not be starved to death, but, in response to repeated hunger strikes by detainees at Guantánamo, the two structures differ on whether captives should be allowed to starve themselves to death. The International Committee of the Red Cross (ICRC) and a growing number of medical ethicists are opposed

(4) On this interrelationship, Rey Chow notes that "only the privileged nations of the world can afford to wage war and preach peace at one and the same time" (2006, page 38). 
to any form of force-feeding, deeming it a clear violation of the prohibition of "cruel, inhuman or degrading treatment or punishment", ensconced in the 1948 Universal Declaration of Human Rights (Crosby et al, 2007). However, as US agents in both the G W Bush and Obama administrations have argued, the hunger strike is a tactic of war; military physician John Edmonson states, the US "will not allow them to do harm to themselves" this way (Wilcox, 2011, page 101). Dismissing the claims of the ICRC, medics at the camp call force-feeding "a life-saving tool" employed by technical experts who "use it every day and ... know it's not as bad as [the detainees] make it out to be" (Rosenberg, 2013). ${ }^{(5)}$ To create even greater discursive distance between legitimate and illegitimate care, the Pentagon refers not to force-feeding, but "re-feeding" (Kaiser, 2014).

This rhetoric is quite different from, for instance, Israel's calculation and management of the number of calories they allowed to enter Gaza as they sought to "put the Palestinians on a diet, but not make them die of hunger" (Weizman, 2012, page 83, italics mine). Unlike the regulated calorie intake of the German 'hunger strategy' employed in the Warsaw Ghetto (Massry and Smogorzewski, 2002), the latter rationale approaches yet avoids governmental practices that will kill, using the "suspended violence" (Ophir and Azoulay, 2005, page 3) of an ever-present threat of forced starvation to govern populations and manage the red line between life and death. The force-feeding chair deploys the language of good intentions to a similar end: the management of calories is aimed not at not making them die, but not letting them manage that red line themselves.

This particular form of care forecloses one of the main avenues for political resistance that remains available to the indefinitely sequestered body. ${ }^{(6)}$ If the state loses control of the terms of death, prisoners in some way have the space to take control of their prison/ bodies. The excess meaning generated by claiming the terms of one's own corporeal death (as opposed to one's political death, which ostensibly occurred with indefinite detention) can circulate in uncontrolled registers within and beyond the prison walls, posing a threat that must be managed. In the processes and objects of force-feeding, care for the biological body is indistinguishable from political violence: a form of humanitarian care targeting the less-than-human body (Butler, 2006, page 98).

Force-feeding is a practice determined entirely by state necropolitics: the sovereign authority over the "power to kill, to allow to live, or to expose to death" (Mbembe, 2003, page 12). It is a technology of violence that seeks to preserve the life of the prisoner so as to control the space and time of their death. While one element of bare life is identified as the condition in which a person can be killed with impunity (Agamben, 1998), here it appears that they can be cared for with the same latitude. The tensions that emerge here trace across a number of blurred thresholds: between the maintenance of life and the prevention of death, between food-as-sustenance and food-as-violence, and, importantly, between death and a continued form of life in detainment.

In the next section I extend this discussion of the imbrication of care and violence in military detention by outlining the flexibility at work in determining the optimal proportion between "common goods and necessary evils" (Weizman, 2012, page 3). Such balance establishes a limit on the use of force that is also a limit on acceptable forms of bodily care and sustenance. First, I note the complex relationships between the ways in which killing and capturing are situated relative to discourses of humanitarian violence. I then investigate how

${ }^{(5)}$ A Navy nurse at Guantánamo was recently relieved of duty pending court martial after he refused to force-feed prisoners (Rosenberg, 2014). In recognizing the detainee body as that of a "morally legitimate sufferer" (Ticktin, 2011, page 10) whose biological and political life are not entirely separate, the nurse's actions did not align with the 'humanity' that underpins care at Guantánamo.

${ }^{(6)}$ For a detailed exploration of prisoners' use of their own bodies as a form of spatial and political resistance, see Allen Feldman's (1991) discussions of hunger strikes and dirty riots in Northern Ireland. 
an understanding of what is acceptable in spaces of detainment is negotiated well beyond the camp walls, and in ways that have more to do with defining the enemy than with an ethic of care.

\section{Relational humanitarianism: between the least good and the least evil}

In a battlefield encounter, the decision to kill or capture inaugurates two very different frameworks. The synergy between these terms is conveyed in the language of doctrine itself, which has long posited that a primary goal of military operations is to 'kill or capture' the enemy: either way, the result is fewer potential killers on the battlefield. This overlap has even extended to calling the recent night raids in Afghanistan-kill/capture raids-implying that on some level there is a kind of parity between the two (cf Edge, 2011). However, while the slash that separates killing from capturing marks a contraction between the two terms, it also recalls an either/or logic: recognition that there remains an important gap between death and continued life in a camp.

Aside from these distinctions, often minimized or erased by discursive practices, other important differences distinguish killing from capturing. Consider, for instance, that the laws of war accommodate "frequent mistakes in the targeting context", which can lead to civilian death or other forms of "collateral damage", but similar errors in detention operations "are widely condemned as lawless" (Waxman, 2008, page 1368). In contemporary war, a certain amount of civilian death is to be expected, and an acceptable civilian body count is determined relative to a framework of proportionality - a limit beyond which damage to civilian lives and objects is seen to outweigh military advantages (Weizman, 2012). By determining these tolerable levels of civilian death, military strategists and legal scholars have together negotiated an economy of violence, a calculated ethical threshold for civilian killing on the battlefield. Weizman, after Hannah Arendt, calls this threshold the "least of all evils"-beyond which war exceeds the limits on violence outlined in IHL (Arendt, 2005, page 36, 37; Weizman, 2012). Death, even a certain degree of civilian death, is somehow given space in this collusion between humanitarian law and military force. It is understood as an unfortunate yet intrinsic part of legitimate war.

In IHL, wrongful detainment, misidentification, and especially death in spaces of detainment, on the other hand, do not figure into this proportional calculus of violence. Performing a wartime capture instigates a different framework for international law, one in which practices such as the use of lethal force, indefinite detainment, and torture ostensibly exceed the bounds of proportionality. This is largely because wartime detention is not a spatial technique aimed specifically at the annihilation of a threat, but, as noted above, one also designed to maintain the life of the enemy in accordance with the minimum requirements of IHL or the basic necessities of biological life. Thus, if violence in the humanitarian present is positioned relative to a 'least of all evils' threshold, wartime detainment seeks at the same time to explore the 'least of all goods': that level of care beyond which violence and military objectives become excessively limited by humanitarian practice and war too closely resembles peace. As such, the spatial practices of capture and detainment generate flexible and flexibly defined "humanitarian gates" (Weizman, 2012, page 83) that recalculate the acceptable thresholds of violence and protection available under IHL.

The contours of these gates are negotiated by numerous actors both within and beyond the concertina wire of the camps. In June of 2005, for example, in response to sustained international criticism of the United States' indefinite detainment and abuse of hundreds at Guantánamo Bay, California Congressman Duncan Hunter held up several plates of food at a press conference and argued that the detainees "have never eaten better, they've never been treated better and they've never been more comfortable in their lives" (CNN, 2005). He noted later that the detainees were in fact being fed too well, that their conditions 
were too good. After all, he said, “[t]hey've all gained weight ... . They had honey-glazed chicken and rice pilaf ... . That's how we treat the terrorists." The level of wartime care, he argued, was even better than the ostensibly peaceful terrain of his political opponents' districts, as detainees have "health care that's better than most HMOs [health maintenance organizations]. And ... something else that no Democrat politician in America has: they live in a place ... where not one person has ever been murdered" (Hunter, 2007).

The negotiations between the least good and the least evil are often established by the demands of relationality and reciprocity, rather than by any kind of fixed ethic. Wartime detention is nearly always positioned as a relational performance whose successes and failures refract off of the enemy's detainment practices and the perceived pathologies of their culture. Perhaps this is a result of the historical legacy of military detention, which was for so long guided by the idea, if not the practice, that a capturing power's treatment of enemy prisoners directly affected that enemy's subsequent treatment of its own prisoners (Springer, 2010). However, such an understanding of the importance of reciprocity is not without political implications, as evidenced in most Cold-War era research devoted to narratives of military detention. Such works tend to discuss these reciprocal relationships after noting a particular deficiency in the American detainment practice: There was disorder in US/UN-managed camps during the Korean War, they note, but always remember that their camps were worse.

This relational juxtaposition forms the basic narrative structure of one of the most cited books on prisoners in the Korean War, William L White's The Captives of Korea (1957). That book moves repeatedly between descriptions of Americans working hard to meet the requirements of the ICRC and the despicable practices of the North Koreans. While the material conditions in the Communist camps were indeed deplorable - and often willfully so-White suggests that the UN camps accurately represented war with humanity, not because they necessarily reflected that practice, but because they were not as awful as the enemy's. Such a narrative essentially guarantees that the enemy is viewed as less than human, while buttressing the humanity of the US and UN camp administrators.

Similar relational discourses were employed when discussing the violence of US-trained and funded soldiers. Such was the case when Life Magazine published images of abuse and abject conditions - including mass graves and overcrowded subterranean 'tiger cages' holding malnourished, tortured, and injured political prisoners - at the provincial prison on the South Vietnamese island of Con Son in 1970 (Harkin, 1970). The United States went to great lengths to position this not as a problem of training, oversight, or adequate investment in South Vietnamese prison infrastructure, but of a particular cultural pathology. Ross Adair, the ranking Republican on the Southeast Asia Committee, declared on NBC News that the torture was evidence of "a system which is Oriental, the standards of which are quite different than ours." He then argued that the use of torture and deprivation in the camp was unrelated to US interests or activities in the region:

"There are things done and tolerated in that part of the world that we would certainly not accept here ... . We are dealing with another sovereign government and we have to respect the rights of that government" (NBC, 1970).

The US did, however, help fund and develop this provincial prison infrastructure. There is also significant evidence suggesting that the CIA trained the national police forces in South Vietnam (and elsewhere) to torture prisoners (Kuzmarov, 2009; McCoy, 2006). Yet Adair and others were nonetheless able to generate discursive distance by embedding the camps in Orientalist narratives. If their camps were not worse than our camps, this was not because of our training, administrative failings, or a lack of oversight. It was because of their culture. This dynamism ultimately troubles the notion that the humanity employed by Americans and their proxies in the camps revolved around a universal humanitarian ethic, or even one that had to do with strategic pragmatism or clear military efficacy. Rather, the 
limits of humanitarian care and protective custody in spaces of detention here seems to be inextricably bound to the violence and practice of the Other: folding "geographic distance into Orientalist hierarchies of human value" (Feldman, 2011, page 330; see also Gregory, 2004). Thus, while the humanity that is the target of humanitarian action initially appears universally applicable, here it is made clear that in the space between the least of all evils and the least of all goods, humanity is in fact "historically, geographically, and politically situated as to have no meaning beyond its particular instantiations" (Feldman and Ticktin, 2010, page 2).

In the next section I turn attention to the sites of battlefield encounter where soldiers capture bodies, focusing on the ways in which the role of humanitarian care in these contact zones (evidenced by the reference to the Geneva Conventions that begins The Enemy in Your Hands above) has recently been fused with technical processes whose objectives are not the care for human life, but the reliable production of data. To do this, I detail the use of digital biometric devices on the battlefield whose incorporation is enabled by the idea that digital technologies can simultaneously help achieve humanitarian objectives and minimize "ambiguity, ambivalence and uncertainty" (Amoore, 2006, page 338). I argue that even as the military has recently increased its focus on generating consistent, reproducible outcomes through the introduction of digital devices, civilian populations are nonetheless exposed to new forms of violence and vulnerability. Attention to the spaces and spatial practices of battlefield apprehension, then, reveals another facet of the unstable interface between military violence and humanitarian ideals.

\section{Governing capture: between humanitarian discourse and technical directives}

In military doctrine and international law, the place where and when a person comes under the control of military forces is called the initial point of capture (POC). Here, bodies are removed from the battlefield, in the hopes of depriving "the opponent of his fighting efficiency" and increasing the chances of victory (Reid, 2000, page 35). Military analysts consider the POC to be "the most critical point in the detainee operations process" (Center for Army Lessons Learned, 2006, page 1). It is also the "most vulnerable period of detainee operations" (US Joint Chiefs of Staff, 2008, pages V-2) as it requires soldiers to "disarm, search, and guard detainees in an unsecured environment" that leaves them exposed to reprisals from other belligerents or their sympathizers (Center for Army Lessons Learned, 2006, page 1). This exposure maps onto all edges of the friend/enemy distinction as, historically, most incidents of wartime detainee abuse and mistreatment occur when a body - enemy or other - crosses or is forced to cross a spatial threshold separating personal freedom and external control. Military doctrine now seeks to account for this, warning that:

"The POC is where most detainee abuse allegations occur; it is the point where emotions following enemy contact may run high ... . Leaders and Soldiers must monitor ... stress to prevent violations of US military policy" (Department of the Army, 2010, pages 4-8).

In passing through this precarious threshold of control, the state's monopoly over the use of deadly force meets one of the limits of liberal political philosophy: while it is acceptable to kill the enemy on the battlefield, it is not acceptable to kill them once they are disarmed. Rousseau was already arguing this point a century before Lieber's Code, noting that the "object of the war" was destroying a political state, and thus:

"the other side has a right to kill its defenders, while they are bearing arms; but as soon as they lay them down and surrender, they cease to be enemies or instruments of the enemy, and become once more merely men, whose life no one has any right to take" (Rousseau, 1968, page 56).

The idealism of political philosophy, however, cannot target the blind spots of Enlightenment governmentality, and it has proven extremely difficult to get combatants to cease to view 
their captives as "enemies or instruments of the enemy". Wartime narratives are full of stories of surrendering troops ambushing their would-be captors, of surrendering forces being assassinated by opposing troops, of those same surrendering bodies being attacked by members of their own military who object to their 'betrayal'. Animating the moment of capture - from either end of the gun's barrel - is the question of whether the encounter will result in death, detention, or continued freedom.

For the military, this space is frequently productive: documents and personal items are removed, catalogued, and initial tactical interrogations are performed in the hopes of rapidly gleaning important information about enemy movements, location, and morale. It is through the performance of this encounter that the prisoners begin their evacuation to the camp. These processes are also the initial stages in producing the new form of life, the first steps towards turning mobile and disruptive actors operating in a violent landscape into a nascent body of legible information: the war prisoner, the detainee, the enemy combatant. ${ }^{(7)}$

Much of what goes on in this interface disappears from view; the military, therefore, has gone to great lengths to use doctrine and training manuals to govern tactics used by combatants who often deploy forms of violence that exceed the calculated bounds of proportionality. Instructions detailing what to do upon encountering and taking prisoners have appeared in doctrine for all service-persons working in theater-not just those carrying weapons or going out on raids - since before the signing of the GPW. Beginning in the Vietnam War, however, combatants were required to take a two-hour training class on the rights of detainees and the laws of war and were given manuals and pocket cards like The Enemy in Your Hands (Prugh, 1975). While there has not been much change in the general tasks set forth, the text has changed significantly, with the past sixty years of doctrinal development boiled down into the recent use of the STRESS technique.

S: SEARCH, look for concealed weapons, documents, and all items out of the ordinary

T: TAG, using form DD 2745 and capture kit. Generate inventory of all detainee belongings

R: REPORT, numbers of detainees to higher echelons.

E: EVACUATE, move quickly out of harm's way.

S: SEGREGATE, keeps detainees from conversing and conspiring

$\mathrm{S}$ : SAFEGUARD, the body of the detainee is to be protected from harm

(Department of the Army, 2001). ${ }^{(8)}$

Manuals often contain a diagram for the safest arrangement of the bodies performing the STRESS technique, urging combatants to maintain an unobstructed line of sight and situating the guard and interpreter in a protective perimeter around the detainee.

Over time, these disciplinary tactics have targeted extremely subtle micropractices and increasingly specific technical objectives. Recent military police training guidebooks, for instance, outline the most effective bodily arrangements and procedural sequences, detailing the proper line of approach (from the front at $45^{\circ}$ ), the correct time to document medical issues (before sending the prisoner on to the collection point), and where to position guards on trucks, buses, and aircraft (Center for Army Lessons Learned, 2006). All of these seek to assure that training and proper military discipline will normalize the judgment and regulate the bodily actions of the American soldier in the field (Foucault, 1979).

Further, as the division between war and policing has blurred (Gregory, 2010; Neocleous, 2014), operations at the POC increasingly come to resemble a crime scene, with

${ }^{(7)}$ The production and determination of these status categories is a dynamic political project with a long and unstable history (cf Mégret, 2006).

${ }^{(8)}$ Between STRESS techniques and stress positions (a torture technique used on detainees) we see two very different forms of detainee handling. Perhaps because of this, when detainee doctrine was updated, STRESS became the " 5 Ss and T technique': search, silence, segregate, speed, safeguard, and tag" (Department of the Army, 2010). 
forensic technologies, assorted digital 'jump-kits', and portable riot control devices used to assure the rapid and consistent handling of the detainee (US Joint Chiefs of Staff, 2008, page IV-6). Each of these devices targets both captor and captive, introducing for the captor a host of procedural steps and mediations meant to generate not only legibility and control, but also evidence that might protect the military against claims of abuse or mismanagement. For the captive, these steps and technologies ostensibly assure consistent treatment or determine a verifiable degree of culpability.

In 2008 the task of filling out paper detainee cards and capture tags was supplemented with the command to rapidly collect and store the subject's digital biometrics - unique biological markers such as fingerprints, iris detail, hand geometry, and facial structure. This enrollment marked "a crucial step that must be conducted as soon as possible" (US Joint Chiefs of Staff, 2008, page IV-one). By 2011 the US military touted digital biometrics as a "game changer" and a fully "operational weapons system" (Biometrics Identity Management Agency, 2012).

Turning the bodies that make up a population into a weapons system (directed back at them) relies on establishing an array of enrollment interfaces that rescales the humanitarian concerns circulating in these sites of encounter, and refracts them through technical ones that generate new vulnerabilities and human rights concerns. The state's understanding of "the body as a site to 'protect' or as a potential agent of 'insecurity'" (Fluri, 2014, page 797) is reflected in the impact of biometric devises on how soldiers act, make decisions, and engage with bodies in the contact zone (Kitchin and Dodge, 2011; Martin, 2010). If a database query yields a 'hit', for instance, the device alerts its user to the enrollee's risk score. Such profiles turn banal encounters between civilians and the military (and its state security proxies) into potential sites of bodily apprehension. ${ }^{(9)}$

Presented with a set of possible actions, the combatant is faced not with a fleeting choice between kill or capture, but with an automated set of risky tiers which run a gamut from detention to mere job disqualification. The decision is affected by the technical parameters of the devices rather than made with situational awareness or by an understanding of immediate threat or danger. Nor do humanitarian or strategic concerns structure battlefield choices. Rather, the device presents the captor with an algorithmic interpretation of potential future riskiness (Amoore, 2013). Despite research challenging the neutrality of these algorithms (Magnet, 2011), the veracity of the information that leads to the decision is here buttressed by an underlying faith that, because actions are automated, the machine's conclusions are likely true, fair, and just.

Digital biometrics enrollment devices establish a sequence of events and procedures that must occur for an acceptable subject portfolio to be compiled. While the distribution of these devices was already widespread by 2006, with thousands in Iraq and Afghanistan, soldiers primarily learned how to use them in the field - often without official guidance, which resulted in a proliferation of unreadable captures and incomplete files (Gabriel, 2011). The Army subsequently established the Training and Doctrine Command Capabilities Manager for Biometrics and Forensics, responsible for ensuring that user requirements are considered and incorporated into Army training. Army, Marine, and Special Operations Command training centers hold classes to assure that enrollments meet baseline legibility standards (Government Accountability Office, 2012).

${ }^{(9)}$ Exemplifying the blurring of boundaries between war and policing and between military and civilian spaces, digital biometrics form a key element in a "series of colonial models" that have boomeranged "back to the West" (Foucault, 2003, page 103). One result has been that biometric technologies are increasingly used in civilian contexts in both honorific and repressive ways (Sekula, 1986). A full accounting of the links between military biometrics and their use in other contexts is extremely important, but remains beyond the scope of this investigation. 
In the field, however, meeting these standards has been difficult. The Defense Department's Biometrics Identity Management Agency has identified systemic errors in their biometric databases that occurred at the technological interface, as soldiers and special operations units performed the space of capture. ${ }^{(10)}$ These include:

- Swapped or duplicate fingers within the left and right hands.

- Swapped hands when referencing the flat four slaps versus the individual rolled fingers.

- Flat four images that are captured without all the fingers present.

- Facial images marked as frontal poses that are not frontal poses.

- Totally white or black facial images.

- Iris images that have shadow or mirrored eyes present (Gabriel, 2011).

A host of new procedures has now been introduced into training programs in order to control these digitized transactions. Indeed, the interface between capture and the camp is defined by these micromanaged performances:

- Moisten enrollee's fingers before capture using the oily areas on the person.

- Slower rolling of individual fingers.

- Avoid tip prints and early lifts

- Pay attention to finger sequencing

- Verify iris captures are done properly to avoid the mirror eyes

- Focus on the poses and captures of the face (Gabriel, 2011).

Once, this care and control was primarily understood through the ethical dictates of the laws of war and the GPW. The biometric encounter, however, is understood not in these ethical terms, nor the political terms of the conflict itself, but through the terms dictated by the digital algorithms themselves (Magnet, 2011) and the banal technical directives and manuals that define the most efficient way of interacting with a technological object. Further, the capturing soldier has a commitment to apprehending and circulating accurate forensic evidence of the encounter. If troops fail to properly administer biometric enrollments, it could mean that a "high value" individual is not apprehended, or the difference "between detaining, retaining, or releasing an insurgent and preventing an incident or picking up the pieces" (Center for Army Lessons Learned, 2008, page 108). Soldiers must take care with the captive's body, take care with their own body, and, now, take care with a digital device that guides their decision making. In these contact zones, what is imagined is a way of thinking about handling bodies on the battlefield in which the challenges of IHL's call for protective custody premised on a recognition of shared humanity are linked with a form of care premised on seeing bodies as discrete, dehumanized sources of data.

While Defense Department officials see digital biometrics as one of the most important tools in organizing the battlefield, others worry that the data might ultimately serve as a 'hit list', exposing civilians to violent reprisals and bodily harm (Shachtman, 2007). Writing to Secretary of Defense Robert Gates, the Electronic Privacy Information Center wrote that the biometric database itself might also be a weapons system in a way that the coders never intended. The linking of the inescapable human body with permanent biometric identifiers in a conflict region "creates an unprecedented human rights risk that could easily be exploited by a future government" (Rotenberg et al, 2007, page 3). One troubling result of this is that the members of the population who seek to utilize the fluidity of identity practices in order to remain out of a conflict, are, by way of these permanent identity markers, drawn headlong

${ }^{(10)}$ BIMA was known as the Biometric Task Force until 2010, when its name was changed to the Biometrics Identity Management Agency (BIMA). In mid-2013, BIMA was again rebranded as the Defense Forensics and Biometric Agency and formalized as a field operating agency. However, the acronym BIMA remains in use when referring to the component that operates and maintains databases in Clarksburg, West Virginia. 
into it. Biometric capture thus initiates a new terrain for the violence that the database ostensibly seeks to curtail in the first place.

\section{Conclusions}

The issues articulated above engage with a seemingly straightforward yet challenging question: how does one understand and govern the encounter and prolonged contact with a battlefield belligerent who, in words often attributed to Winston Churchill, "tries to kill you and fails, and then asks you not to kill him?" Beyond the strategic or tactical issues that emerge when a body is detained on the battlefield, it is important not to lose sight of the fact that capture and evacuation, and indeed military detainment, often occur in vulnerable and precarious landscapes with extremely limited food and water supply for both captors and detainees, in places far removed from oversight or direct command. As I describe above, the legacies of mistreatment and violence that map onto these spaces ultimately led to the introduction of an international legal structure that dramatically changed both the framing and the practice of military detention by the US and its proxies. My primary objective here has not been to challenge the very real benefits this has brought to many military captives. Rather, my aim has been to describe the collusion of violence and care within the landscape of military detainment and to complicate the thresholds that mark the unstable and frequently violent contours of what Weizman (2012) calls the "humanitarian present."

Over the course of the past sixty years, then, practices of military detainment - balanced precariously between the lethality of war and a logic of care-have been transformed from largely unregulated sites of interpersonal encounter to technologically mediated, highly choreographed, and spatially expansive interfaces that seek to administer and control entire populations. Despite these legal and technological developments, the relationships between practices of wartime detainment, the EPW's status hors de combat, and the evolving violent practices of late modern warfare have not been fixed or clearly delineated. Thus, while the ways in which the military defines the battlefield "may still define the privilege to kill", and humanitarian actors simultaneously "want to define the not-battlefield to open a space for humanitarian law", this does not mean that these spatial imaginaries can be so cleanly or clearly divided (Mégret, 2012, page 4). Many of the attempts to make the landscape of war more humane carry simultaneously with them work that obscures the geographies of the violence, blood, and destruction that still remain at war's center. Ultimately, the roles that humanitarian ideals have played in limiting, reframing, and restructuring the landscape of violence often end up being utilized by the state to justify and expand its violent practices.

\section{References}

Agamben G, 1998 Homo Sacer: Sovereign Power and Bare Life (Stanford University Press, Palo Alto, CA)

Agamben G, 2005 State of Exception (University of Chicago Press, Chicago, IL)

Amoore L, 2006, "Biometric borders: governing mobilities in the war on terror" Political Geography $25336-351$

Amoore L, 2013 The Politics of Possibility: Risk and Security Beyond Probability (Duke University Press, Durham, NC)

Anderson B, 2011, "Facing the future enemy: US counterinsurgency doctrine and the pre-insurgent" Theory, Culture and Society 28(7-8) 216-240

Arendt H, 2005 Responsibility and Judgment (Schocken, New York)

Barnett M N, 2011 Empire of Humanity: A History of Humanitarianism (Cornell University Press, Ithaca, NY)

Biometrics Identity Management Agency, 2012, “Biometrics 2012”, Biometrics Identity Management Agency, Department of Defense, http://www.biometrics.dod.mil/Files/Nideos/Biometrics_2012.wmv 
Bonds A, 2006, "Profit from punishment? The politics of prisons, poverty and neoliberal restructuring in the rural American Northwest" Antipode 38 174-177

Brauman R, 2004, "From philanthropy to humanitarianism: remarks and an interview" South Atlantic Quarterly 103(2-3) 397-417

Butler J, 2006, Precarious Life: The Powers of Mourning and Violence (Verso, New York)

Center for Army Lessons Learned, 2006 Detainee Operations at the Point of Capture: Tactics, Techniques, and Procedures Combined Arms Center, Fort Leavenworth, KS

Center for Army Lessons Learned, 2008 Military Police and Counterinsurgency Operations Operation Iraqi Freedom Initial Impressions Report Combined Arms Center, Fort Leavenworth, KS

Chow, R, 2006 The Age of the World Target: Self-referentiality in War, Theory, and Comparative Work (Duke University Press, Durham, NC)

CNN, 2004, "GITMO treatment" CNN: Breaking News, http://www.democraticunderground.com/discuss/duboard.php?az=view_all\&address=132×1852187

Crosby S S, Apovian C, Grondin M, 2007, "Hunger strikes, force-feeding, and physicians' responsibilities" JAMA: The Journal of the American Medical Association 298 563-566

Davis G W, 1977, "Prisoners of war in twentieth-century war economies" Journal of Contemporary History 12 623-634

Department of the Army, 2001 FM 3-19.40 Internment/Resettlement Operations US Government Printing Office, Washington, DC

Department of the Army, 2010 FM 3-39.40 Internment / Resettlement Operations US Government Printing Office, Washington, DC

Dillon M, Reid J, 2009 The Liberal Way of War: Killing to Make Life Live (Routledge, London)

Doyle R C, 2010 The Enemy in Our Hands: America's Treatment of Prisoners of War from the Revolution to the War on Terror (University Press of Kentucky, Lexington, KY)

Edge D, 2011, "Kill/capture" Frontline, http://video.pbs.org/video/1917910631/

Edkins J, 2003, "Humanitarianism, humanity, human" Journal of Human Rights 2 253-258

Fassin D, 2010, "Inequalities of lives, hierarchies of humanity: moral commitments and ethical dilemmas of humanitarianism", in In the Name of Humanity: The Government of Threat and Care Eds I Feldman, M Ticktin (Duke University Press Books, Durham, NC) pp 238-255

Feldman A, 1991 Formations of Violence: The Narrative of the Body and Political Terror in Northern Ireland (University Of Chicago Press, Chicago, IL)

Feldman I, Ticktin M (Eds), 2010 In the Name of Humanity: The Government of Threat and Care (Duke University Press Books, Durham, NC)

Feldman K P, 2011, "Empire's verticality: the Af/Pak frontier, visual culture, and racialization from above" Comparative American Studies 9 325-341

Fluri J L, 2014, "States of (in)security: corporeal geographies and the elsewhere war" Environment and Planning D: Society and Space 32 795-814

Foucault M, 1979 Discipline and Punish: The Birth of the Prison (Vintage Books, New York)

Foucault M, 2003 "Society Must Be Defended": Lectures at the Collège de France, 1975-1976 (Picador, New York)

Gabriel C A, 2011, "BIMA quality control/accuracy observations", http://www.biometrics.org/bc2011/presentations/DoD/02_BIMA_Quality_Control-BCC_2011.pdf

Gebhardt J F, 2005 The Road to Abu Ghraib: US Army Detainee Doctrine and Experience (Combined Studies Institute Press, Fort Leavenworth, KS)

Gilmore R W, 2007 Golden Gulag: Prisons, Surplus, Crisis, and Opposition in Globalizing California (University of California Press, Berkeley, CA)

Government Accountability Office, 2012, "Defense biometrics: additional training for leaders and more timely transmission of data could enhance the use of biometrics in Afghanistan", Government Accountability Office, Washington, DC, http://gao.gov/assets/600/590311.pdf

Gregory D, 2004 The Colonial Present: Afghanistan, Palestine, Iraq (Wiley-Blackwell, Malden, MA) Gregory D, 2010, "War and peace" Transactions of the Institute of British Geographers, New Series 35 154-186

Harkin T (photographer), 1970, “The tiger cages of Con Son: a congressional investigating committee finds secret cells in a concentration camp for South Vietnamese political prisoners" Life 69(3) 26-29 
Hunter D, 2007, "Transcript: Republican Presidential Primary Debate", http://www.foxnews.com/story/2007/09/05/transcript-republican-presidential-primary-debate

International Conferences (The Hague), 1907, "Hague Convention (IV) Respecting the Laws and Customs of War on Land and Its Annex", http://www.unhcr.org/refworld/docid/4374cae64.html

Kaiser M, 2014, "Death in Camp Delta" Guernica, http://www.guernicamag.com/features/death-in-camp-delta/

Khalili L, 2012 Time in the Shadows: Confinement in Counterinsurgencies (Stanford University Press, Palo Alto, CA)

Kim M, 2011 Humanity Interrogated: Empire, Nation, and the Political Subject in U.S. and UNcontrolled POW Camps of the Korean War, 1942-1960 Dissertation, Department of History, University of Michigan, Ann Arbor, MI

Kitchin R, Dodge M, 2011 Code/Space: Software and Everyday Life (MIT Press, Cambridge, MA)

Krammer A, 2007 Prisoners of War: A Reference Handbook (Praeger, Westport, CT)

Kuzmarov J, 2009, "Modernizing repression: police training, political violence, and nation-building in the "American Century" Diplomatic History 33 191-221

Lieber F, 1863, "Instructions for the Government of Armies of the United States in the Field (Lieber Code)"

Loyd J M, Mitchelson M, Burridge A (Eds), 2012 Beyond Walls and Cages: Prisons, Borders, and Global Crisis (University of Georgia Press, Athens, GA)

McCoy A, 2006 A Question of Torture: CIA Interrogation, from the Cold War to the War on Terror (Henry Holt, New York)

Magnet S A, 2011 When Biometrics Fail: Gender, Race, and the Technology of Identity (Duke University Press, Durham, NC)

Martin L L, 2010, "Bombs, bodies, and biopolitics: securitizing the subject at the airport security checkpoint" Social and Cultural Geography 11(1) 17-34

Martin L L, Mitchelson M L, 2009, "Geographies of detention and imprisonment: interrogating spatial practices of confinement, discipline, law, and state power" Geography Compass 3(1) 459-477

Massry S G, Smogorzewski M, 2002, "The hunger disease of the Warsaw Ghetto" American Journal of Nephrology 22(2-3) 197-201

Mbembe A, 2003, "Necropolitics" Public Culture 15(1) 11-40

Mégret F, 2006, "From 'savages' to 'unlawful combatants': a postcolonial look at international humanitarian law's 'other'", in International Law and its Others Ed. A Orford (Cambridge University Press, Cambridge) pp 265-317

Mégret F, 2012, "War and the vanishing battlefield" Loyola University Chicago International Law Review 9(1) 1-21

Moran D, 2013, "Between outside and inside? Prison visiting rooms as liminal carceral spaces" GeoJournal 78 339-351

NBC, 1970, "South Vietnam/Con Son Prison" NBC Evening News, http://tvnews.vanderbilt.edu/tvn-video-view.pl?RC=452469

Neff S C, 2010, "Prisoners of war in international law: the nineteenth century", in Prisoners in War Ed. S Scheipers (Oxford University Press, Oxford; New York) pp 57-73

Neocleous M, 2014 War Power, Police Power (Edinburgh University Press, Edinburgh)

Ophir A, Azoulay A, 2005, “The monster's tail”, in Against the Wall: Israel's Barrier to Peace Ed. M Sorkin (New Press, New York) pp 2-28

Palmer-Fernández G, 2001, "White flags on the road to Basra: surrendering soldiers in the Persian Gulf War" Journal of Social Philosophy 32 143-156

Pfanner T, 2006, "Methods of warfare: interview with General Sir Rupert Smith" International Review of the Red Cross 88(864) 719-727

Pratt M L, 1992 Imperial Eyes: Travel Writing and Transculturation (Routledge, New York) Prugh G S, 1955, "Prisoners at war: the POW battleground" Dickinson Law Review 60 123-138

Prugh G S, 1975 Vietnam Studies: Law at War: Vietnam 1964-1973 Department of the Army, Washington, DC 
Reid P, 2000 Prisoner of War: The Inside Story of the POW from the Ancient World to Colditz and After (Bounty Books, London)

Reid-Henry S M, 2013, "Humanitarianism as liberal diagnostic: humanitarian reason and the political rationalities of the liberal will-to-care" Transactions of the Institute of British Geographers, New Series 39 418-431

Rosenberg C, 2013, “Guantánamo medics: forced-feedings aren't torture” The Miami Herald, http://www.miamiherald.com/static/media/projects/gitmo_chart/index.html

Rosenberg C, 2014, "Case of Navy nurse who refused to force-feed could put Guantánamo hunger strike on trial" The Miami Herald, http://www.miamiherald.com/static/media/projects/gitmo_chart/index.html

Rotenberg M, Davies S, Roth K, 2007, "Letter to Secretary of Defense Robert M. Gates regarding US biometric identity system of Iraqis", http://www.epic.org/privacy/biometrics/epic_iraq_dtbs.pdf

Rousseau J-J, 1968 The Social Contract (Penguin, Harmondsworth, Middx)

Scheipers S (Ed.), 2010 Prisoners in War (Oxford University Press, Oxford)

Sekula A, 1986, "The body and the archive" October 39 3-64

Shachtman N, 2007, "Iraq's biometric database could become 'hit list': army” Wired Magazine: Danger Room, http://www.wired.com/dangerroom/2007/08/also-two-thirds/\#_jmp0_

Smith R, 2007 The Utility of Force: The Art of War in the Modern World (Knopf, New York)

Springer P J, 2010 America's Captives: Treatment of POWs from the Revolutionary War to the War on Terror (University Press of Kansas, Lawrence, KS)

Ticktin M I, 2011 Casualties of Care: Immigration and the Politics of Humanitarianism in France (University of California Press, Berkeley, CA)

US Joint Chiefs of Staff, 2008 JP 3-63 Detainee Operations US Joint Chiefs of Staff, Washington, DC von Clausewitz C, 1989 On War (Princeton University Press, Princeton, NJ)

Waxman M C, 2008, "Detention as targeting: standards of certainty and detention of suspected terrorists" Columbian Law Review 108 1365-2098

Weizman E, 2012 The Least of All Possible Evils: Humanitarian Violence from Arendt to Gaza (Verso, New York)

White W L, 1957 The Captives Of Korea: An Unofficial White Paper On The Treatment Of War Prisoners; Our Treatment of Theirs: Their Treatment of Ours (Scribners, New York)

Wilcox L, 2011, "Dying is not permitted: sovereignty, biopower, and force-feeding at Guantanamo Bay", in Torture: Power, Democracy, and the Human Body Eds S Biswas, Z Zalloua (University of Washington Press, Seattle, WA) pp 101-128

Zehfuss M, 2012, "Contemporary Western war and the idea of humanity" Environment and Planning D: Society and Space 30 861-876

Zillman, D N, 1975, "Political uses of prisoners of war" Arizona State Law Journal 6(2) 237-255

Žižek S, 2002, “Are we in a war? Do we have an enemy?" London Review of Books 24(10) 3-6 